\title{
Changes in Maize (Zea mays L.) Performance and Nutrients Content with the Application of Poultry Manure, Municipal Solid Waste and Ash Composts
}

\author{
N. M. John ${ }^{1}$, D. F. Uwah ${ }^{1}$, O. B. $\operatorname{Iren}^{1} \&$ J. F. Akpan ${ }^{1}$ \\ ${ }^{1}$ Department of Soil Crop, Faculty of Agriculture, Forestry and Wildlife Resources Management, University of \\ Calabar, Nigeria \\ Correspondence: N. M. John, Department of Soil Crop, Faculty of Agriculture, Forestry and Wildlife Resources \\ Management, University of Calabar, Nigeria. Tel: 234-806-116-3822. E-mail: drnmjohn@yahoo.com
}

\author{
Received: May 8, 2012 Accepted: July 23, 2012 Online Published: February 17, 2013 \\ doi:10.5539/jas.v5n3p270 URL: http://dx.doi.org/10.5539/jas.v5n3p270
}

\begin{abstract}
This research was carried out at the Teaching and Research Farm of the University of Uyo, Nigeria to study the effect of applying compost made from poultry manure, municipal waste and ash on maize growth and yield. The composting of the organic wastes was done using a dry weight ratio of 3:1:0.5 of poultry manure, municipal solid waste (sorted) and ash, respectively. The finished compost was applied to the maize in polythene bags at the rates of 0, 10, 20 and $40 \mathrm{t} \mathrm{ha}^{-1}$. Each of these treatments was replicated four times. Eight maize seeds were planted per bag for six weeks during which soil samples were collected. Standard laboratory analysis was carried out on experimental soil, compost and maize plants samples. The mean plant height, root length and number of roots of maize planted on the control (soil only) were significantly $(\mathrm{P}<0.05)$ lower than those on all the compost fertilized treatments from 14 to 42 days after planting (DAP). Dry matter (\%) of maize plant at 42 DAP indicated significant differences $(\mathrm{P}<0.05)$ among all the treatments. Among the micronutrients $\mathrm{Cr}$ was not detected, $\mathrm{Cd}$ maintained a constant level of $2.60 \mathrm{mg} \mathrm{kg}^{-1}$ in both compost fertilized and unfertilized maize plants, while $\mathrm{Fe}$, $\mathrm{Mn}$ and Co were found in lower amounts in plants fertilized with compost than in the soil only. Maize plants fertilized with various compost treatments performed better than those planted on soil only due to enhancement by the organic matter and various nutrients contained in the composts.
\end{abstract}

Keywords: Maize, performance, nutrient content, heavy metals, compost

\section{Introduction}

One of the greatest problems facing most African countries is the inability to grow enough food for her ever-increasing population. One of the constraints is the inherent low fertility of the soils. Research also indicates that a considerable part of the required nitrogen and potassium for intensive cropping could be met by including legumes in crop rotation and by recycling nutrients through the application of good quality compost (Agboola, 1974).

Urban or municipal compost can be detrimental to farming if proper characterization is not done. Sobulo (2000) agreed with this when he reported that proper soil test should be carried out before applying both organic and mineral fertilizer to Zea mays. Research on the use of organic manure for arable crop production in Nigeria dates back to almost a century now, starting with the pioneering work of Harthey and Greenwood (1933). The main thrust of these early studies was focused on the nutrients in a series of experiments conducted between 1934 and 1940. Recently, in Nigeria and the tropics in general, more work had been done on the effect of applying organic manures to various crops (Uko et al., 2009; John et al., 2010, 2011; Iren et al., 2011, Uwah et al., 2011). This is because of the ever-degrading soil fertility status of her soils due to reduction in organic matter content.

Reduction in soil organic matter also leads to nutrient imbalance resulting in poor crop growth and yield (Lal \& Kang, 1982). The main role of animal manures in the maintenance of soil fertility is as a supplier of plant nutrients, particularly nitrogen, phosphorus and a wide range of trace elements. The effect of heavy metals on plants nutrition (most of which are micronutrients) and crop responses have been studied mostly for maize, cotton, and tree crops such as cocoa and oil palm (Lombin \& Abdullahi, 1978; John, 2007). However, Esenowo (1994) reported that $\mathrm{Zn}, \mathrm{Cu}, \mathrm{Pb}, \mathrm{Ni}$ are the sources of toxicity found most frequent in higher plants, but the level at which heavy metals may become toxic to plants varies greatly with environmental conditions (Baath et al., 1998). 
For the chemical composition of some poultry materials; chicken or poultry manure is a rich fertilizer amendment with nutrient values that can ran up to $30 \% \mathrm{~N}, 4 \% \mathrm{P}$ and $3 \% \mathrm{~K}$ (Lorton, 1996). He also estimated that an average dressing of $10 \mathrm{~kg} \mathrm{ha}^{-1}$ farmyard manure would supply about $50 \mathrm{~kg} \mathrm{~N}^{-1} \mathrm{ha}^{-1}, 30 \mathrm{~kg} \mathrm{P}_{2} \mathrm{O}_{5} \mathrm{ha}^{-1}$ and 50 $\mathrm{Kg} \mathrm{K}_{2} \mathrm{O}$ ha $^{-1}$.

Farmers in this part of the world use fresh poultry manure as a major organic source for soil fertility improvement and increase in their crop yields, totally ignoring the commonly available municipal waste and ash. Against this background, this research was conducted using poultry manure, municipal waste and ash to prepare organic compost, determine its nutrient concentration and evaluate its effect on the performance of maize in a sandy loam soil in the humid tropics.

\section{Materials and Methods}

The composting was carried out in John Ker Nigeria Company, Ikot Ekpene whereas the polybag experiment as conducted at the University of Uyo Teaching and Research Farm, both in Akwa Ibom State, Nigeria.

Ash (As) was collected from a palm oil mill, Poultry droppings (Pd) acquired from layers pen after two months of accumulation and market waste from Ikot Ekpene main market. The poultry manure, market waste and ash were mixed in the ratio 3:1:0.5 (dry weight basis), respectively. After the initial mixture of the components, the compost heap was manually stirred every 3 days for the first 2 weeks, once a week for the next 2 weeks and once in 2 weeks for the rest of the composting period. At each stirring, adequate water was added to the compost windrow, during which samples were collected for laboratory analysis.

A green house with ambient temperature and relative humidity maintained at between 28 and $30^{\circ} \mathrm{C}$ and 85 and $95 \%$, respectively was used for the planting of maize for six weeks. Four treatments namely; 0, 10, 20 and $40 \mathrm{t}$ $\mathrm{ha}^{-1}$ of the compost was applied at $0,50,100$ and $200 \mathrm{~g}$ per polythene bag of $10 \mathrm{~kg}$ sandy loam soil, respectively. Each treatment had 4 replications. The different treatments were bagged, labeled and arranged in a Completely Randomized design in the Teaching and Research Farm of the University of Uyo. An improved and open pollinated hybrid variety of maize DMR-LSR TSD was treated with Apron plus before planting. Eight seeds were planted in each bag and later thinned to five. Weeding was manually done by hand picking after every two weeks.

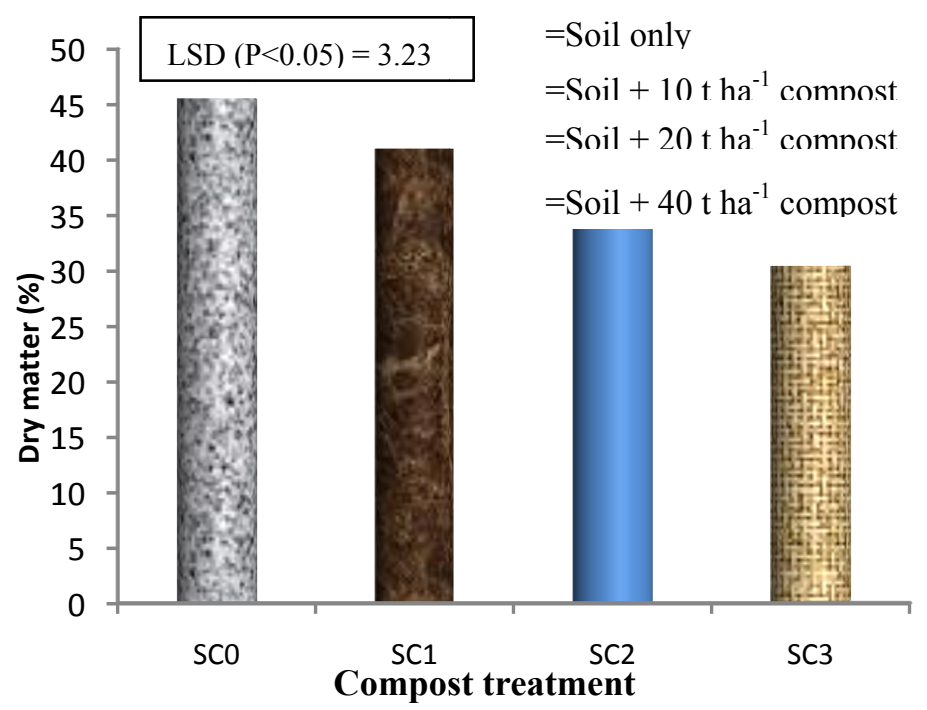

Figure 1. Mean dry matter weight of maize as influenced by various rates of compost treatment at 6 weeks after planting

\subsection{Chemical Analysis of Compost and Soil Samples}

Composite soil sample of the experimental site was collected at the soil depths of 0-15 and 15-30 cm, labeled, air-dried, and sieved through a $2 \mathrm{~mm}$ mesh for physico-chemical analysis. Organic carbon was determined using Walkley-Black method as described by Nelson and Sommers (1982). Total nitrogen was determined by macro-kjeldahl procedures (Jackson, 1962). Available phosphorus was extracted using Bray P-1 method as 
described by Bray and Kurtz (1945) and P in the extract measured by the colour method of Murphy and Riley (1962). Exchangeable acidity was extracted with IN KCI and determined by titration. $\mathrm{pH}$ was determined in a 1:2 soil/water ratio using a digital $\mathrm{pH}$ meter. Exchangeable bases were extracted with $\mathrm{IN} \mathrm{NH}_{4} \mathrm{OAc}$, while $\mathrm{Ca}^{2+}$ and $\mathrm{Mg}^{2+}$ were determined by EDTA titration, and $\mathrm{K}^{+}$and $\mathrm{Na}^{+}$were measured by the flame analyzer. Particle size distribution was determined by the hydrometer method of Bouyoucos (1962). Micronutients content of plant sample were determined using analytical method described by Udo et al. (2009).

Data collected included plant height, root length and dry matter of the maize at six weeks after planting. And these were subjected to analysis of variance (ANOVA) and means were compared with Fishers' Least Significance Difference (LSD) at $5 \%$ level of probability (Gomez \& Gomez, 1994).

\section{Results and Discussion}

Plant nutrient contents of the organic materials used for the preparation of the compost varied among the various organics as shown in Table 1. Poultry dropping contained the highest amount of organic matter, Total N, P and $\mathrm{K}$ than market waste and palm oil ash. The $\mathrm{pH}$ of all the organic materials were alkaline but market waste and palm oil ash possessed very low moisture compared with poultry dropping.

Table 1. Nutrient and moisture contents of the organic materials used for the composting process

\begin{tabular}{lcccccccc}
\hline $\begin{array}{l}\text { Organic } \\
\text { Material }\end{array}$ & $\mathrm{pH}$ & Org. mat (\%) & $\begin{array}{c}\text { Total N } \\
(\%)\end{array}$ & $\begin{array}{c}\text { Avail. P } \\
\left(\mathrm{mg} \mathrm{kg}^{-1}\right)\end{array}$ & $\begin{array}{c}\mathrm{K} \\
\left(\mathrm{mg} \mathrm{kg}^{-1}\right)\end{array}$ & $\begin{array}{c}\mathrm{Ca} \\
\left(\mathrm{mg} \mathrm{kg}^{-1}\right)\end{array}$ & $\begin{array}{c}\mathrm{Mg} \\
\left(\mathrm{mg} \mathrm{kg}^{-1}\right)\end{array}$ & $\begin{array}{c}\text { Moisture } \\
(\%)\end{array}$ \\
\hline Palm oil ash & 9.5 & 1.2 & 0.25 & 1.87 & 26.1 & 0.71 & 0.52 & 1.7 \\
Market waste & 6.8 & 3.4 & 0.19 & 0.74 & 25.8 & 0.53 & 0.22 & 10.2 \\
Poultry dropping & 8.6 & 51.7 & 1.20 & 59.8 & 7400.0 & 0.42 & 0.08 & 43.5 \\
\hline
\end{tabular}

The $\mathrm{pH}$ levels of the soil at six weeks after planting under all the compost treatments were higher than its value before planting. This might results from the inclusion of ash in the compost whose high content of $\mathrm{K}$ and $\mathrm{Ca}$ reduced the acidity of this soil. The soil chemical properties such as $\mathrm{C}, \mathrm{N}, \mathrm{P}, \mathrm{Ca}, \mathrm{K}, \mathrm{Mg}$ and $\mathrm{Na}$ at six weeks after planting increased with increase in the application rates but were generally lower in soil content than before the planting of the maize as presented on Table 2. The high organic matter content of the compost enhanced the absorption of nutrients and water by the growing plant which highly affected the level of nutrients in the soil at the end of the experiment.

Table 2. Some chemical properties of experimental soil before and after planting

\begin{tabular}{lllllll}
\hline \multirow{2}{*}{ Chemical properties } & \multirow{2}{*}{ Soil content before planting } & \multicolumn{5}{c}{ Soil content after planting } \\
\cline { 3 - 7 } & & $\mathrm{SC}_{0}$ & $\mathrm{SC}_{1}$ & $\mathrm{SC}_{2}$ & $\mathrm{SC}_{3}$ & Mean \\
\hline $\mathrm{pH}$ & 4.86 & 4.52 & 6.77 & 7.81 & 7.86 & 6.36 \\
Org. C (\%) & 6.00 & 5.80 & 6.80 & 7.00 & 7.30 & 6.58 \\
Total N (\%) & 0.52 & 0.39 & 0.58 & 0.60 & 0.63 & 0.54 \\
$\mathrm{Ca}(\%)$ & 0.40 & 0.20 & 0.24 & 0.28 & 0.32 & 0.29 \\
$\mathrm{Mg}(\%)$ & 0.32 & 0.23 & 0.20 & 0.22 & 0.24 & 0.22 \\
$\mathrm{~K}\left(\mathrm{mgkg}^{-1}\right)$ & 460.00 & 360.00 & 400.00 & 460.00 & 500.00 & 445.00 \\
$\mathrm{Na}\left(\mathrm{mgkg}^{-1}\right)$ & 170.00 & 100.00 & 100.00 & 100.00 & 110.00 & 116.00 \\
$\mathrm{P}\left(\mathrm{mgkg}^{-1}\right)$ & 600.00 & 370.00 & 400.00 & 450.00 & 500.00 & 430.00 \\
$\mathrm{C} / \mathrm{N} \mathrm{ratio}$ & 11.53 & 11.84 & 11.67 & 11.72 & 11.59 & 11.67 \\
\hline
\end{tabular}

Key: $\mathrm{SC}_{0}=$ Soil only; $\mathrm{SC}_{1}=$ Soil $+10 \mathrm{t} \mathrm{ha}^{-1}$ compost; $\mathrm{SC}_{2}=$ Soil $+20 \mathrm{t} \mathrm{ha}^{-1}$

compost; $\mathrm{SC}_{3}=$ Soil $+40 \mathrm{t} \mathrm{ha}^{-1}$ compost. 
The contents of $\mathrm{Cu}$ and $\mathrm{Mn}$ were higher at the commencement of composting compared to all other heavy metals whose content were higher at the end of composting, resulting from the mineralization process during microbial decay of the various organic materials. However, very low levels of $\mathrm{Cd}, \mathrm{V}$ and Co were detected in the finished compost as shown on Table 3 .

Table 3. The initial and final content of heavy metals in the compost

\begin{tabular}{lllllllllll}
\hline Compost & \multicolumn{10}{c}{ Heavy metals content $\left(\mathrm{mg} \mathrm{kg}^{-1}\right)$} \\
\cline { 2 - 11 } Status & $\mathrm{Cr}$ & $\mathrm{Cu}$ & $\mathrm{Mn}$ & $\mathrm{Fe}$ & $\mathrm{Ni}$ & $\mathrm{V}$ & $\mathrm{Cd}$ & $\mathrm{Co}$ & $\mathrm{Pb}$ & $\mathrm{Zn}$ \\
\hline Initial & 25.00 & 45.00 & 466.7 & 2930.2 & 8.70 & 0.50 & 0.90 & 2.20 & 11.10 & 217.10 \\
Final & 62.50 & 30.00 & 358.3 & 4279.1 & 78.3 & 4.00 & 1.90 & 8.90 & 50.00 & 670.00 \\
\hline
\end{tabular}

The $\mathrm{pH}$ levels of all the maize plants with or without compost application were alkaline in reaction and also increased with increase in the rate of application of the compost to the crop plant.

Apart from some exchangeable cations such as $\mathrm{Ca}, \mathrm{Mg}$, $\mathrm{Na}$ and $\mathrm{P}$ contents of the growing maize plant, the uptake of $\mathrm{C}, \mathrm{N}$ and $\mathrm{K}$ on treatments fertilized with compost were higher than the control (soil alone), though these elements increased slightly with increase in the rate of applied compost. These are shown on Table 4. However, the uptake of $\mathrm{Ca}$ by plants in all the fertilized treatments was lower than that of the untreated plants in the control (soil only).

Table 4. Micronutrients content of maize plant at six weeks after planting influenced by different rate of compost application

\begin{tabular}{cccccc}
\hline & \multicolumn{5}{c}{ Plant nutrient content $\left(\mathrm{mg} \mathrm{kg}^{-1}\right)$} \\
\cline { 2 - 6 } Heavy metals & $\mathrm{SC}_{0}$ & $\mathrm{SC}_{1}$ & $\mathrm{SC}_{2}$ & $\mathrm{SC}_{3}$ & Mean \\
\hline $\mathrm{Cu}$ & 30.00 & 25.00 & 20.00 & 40.00 & 28.75 \\
$\mathrm{Mn}$ & 266.60 & 201.00 & 108.40 & 233.40 & 202.35 \\
$\mathrm{Fe}$ & 4241.80 & 3632.30 & 3237.20 & 1460.40 & 3142.93 \\
$\mathrm{Ni}$ & 104.40 & 100.00 & 87.00 & 165.20 & 114.20 \\
$\mathrm{~V}$ & 3.00 & 2.10 & 1.60 & 5.00 & 2.93 \\
$\mathrm{Cd}$ & 2.60 & 2.60 & 2.60 & 2.60 & 2.60 \\
$\mathrm{Co}$ & 11.20 & 7.10 & 6.60 & 4.40 & 7.33 \\
$\mathrm{~Pb}$ & 33.40 & 34.30 & 35.49 & 44.20 & 29.52 \\
$\mathrm{Zn}$ & 165.80 & 155.30 & 101.40 & 605.80 & 257.08 \\
$\mathrm{Cr}$ & $\mathrm{ND}$ & $\mathrm{ND}$ & $\mathrm{ND}$ & $\mathrm{ND}$ & \\
\hline
\end{tabular}

Key: $\mathrm{ND}=$ Not detected; $\mathrm{SC}_{0}=$ Soil only; $\mathrm{SC}_{1}=$ Soil +10 tha $^{-1}$ compost;

$\mathrm{SC}_{2}=$ Soil $+20 \mathrm{t} \mathrm{ha}^{-1}$ compost $\mathrm{SC}_{3}=$ Soil $+40 \mathrm{tha}^{-1}$ compost.

\subsection{Changes in Micronutrients Content of Maize Plants.}

The application of different rates of the composts containing various levels of micronutrients to the maize plants on soil with poor nutrients content and low $\mathrm{pH}$ (4.86) resulted in changes in their plant contents at six weeks after planting. Whereas $\mathrm{Cr}$ was not detected in the maize plants under both fertilized and unfertilized treatments, micronutrients such as $\mathrm{Fe}, \mathrm{Mn}$ and Co were found in lower amounts in the compost fertilized plants than in the soil only (Table 4). However, Cd which had the least content of $1.69 \mathrm{mg} \mathrm{kg}^{-1}$ in the finished compost maintained a constant level of $2.60 \mathrm{mg} \mathrm{kg}^{-1}$ in all the plants whether treated or not with compost. Carroll (2011) reported that the amount of any micronutrient absorbed depends on the plant's response to the nutrient, bioavailability of the nutrient and concentration of the nutrient around the root's surface of the plant. 


\subsection{Influence of Different Rates of Applied Compost on the Growth Components of Maize}

The mean root length, root number and maize plant height increased with increase in the time of planting, both on soil alone and on soil with different rates of compost application. Maize plants that received $40 \mathrm{tha}^{-1}$ compost had the highest means root length, root number and plant height while maize plants on soil alone had the lowest of these components.

The mean plant height $(\mathrm{cm})$ of maize plants with the different levels of compost application taken at 7, 14, 21, 28, 35 and 42 days after planting (DPA) were significantly different $(\mathrm{P}<0.05)$ among the various treatment as shown in Table 3. Maize plants on soil fertilized with $40 \mathrm{t} / \mathrm{ha}$ compost had the highest height as represented on Table 5.

Table 5. Influence of applied compost on plant nutrient content of maize at six weeks after planting

\begin{tabular}{lccccc}
\hline \multirow{2}{*}{ Properties } & \multicolumn{5}{c}{ Plant nutrient content } \\
\cline { 2 - 6 } & $\mathrm{SC}_{0}$ & $\mathrm{SC}_{1}$ & $\mathrm{SC}_{2}$ & $\mathrm{SC}_{3}$ & Mean \\
\hline $\mathrm{pH}$ & 8.10 & 8.34 & 8.70 & 8.72 & 8.47 \\
Organic C (\%) & 12.60 & 13.80 & 13.80 & 13.90 & 13.53 \\
Total N (\%) & 1.14 & 1.16 & 1.16 & 1.17 & 1.16 \\
$\mathrm{Ca}(\%)$ & 0.048 & 0.030 & 0.040 & 0.040 & 0.04 \\
$\mathrm{Mg}(\%)$ & 0.11 & 0.08 & 0.09 & 0.12 & 0.10 \\
$\mathrm{~K}\left(\mathrm{mg} \mathrm{kg}^{-1}\right)$ & 10000.00 & 16000.00 & 29000.00 & 30000.00 & 18000.00 \\
$\mathrm{Na}\left(\mathrm{mg} \mathrm{kg}^{-1}\right)$ & 110.00 & 120.00 & 120.00 & 140.0 & 122.50 \\
$\mathrm{P}\left(\mathrm{mg} \mathrm{kg}^{-1}\right)$ & 5800.00 & 1000.00 & 2600.00 & 6800.00 & 4050.00 \\
$\mathrm{C} / \mathrm{N}$ & 11.10 & 11.90 & 11.90 & 12.10 & 11.75 \\
\hline
\end{tabular}

Key: $\mathrm{SC}_{0}=$ Soil only; $\mathrm{SC}_{1}=$ Soil $+10 \mathrm{t} \mathrm{ha}^{-1}$ compost; $\mathrm{SC}_{2}=$ Soil $+20 \mathrm{t} \mathrm{ha}^{-1}$ compost;

$\mathrm{SC}_{3}=$ Soil $+40 \mathrm{tha}^{-1}$ compost.

Mean root number and root length of the maize plants followed the same trend as mean plant height. However, mean root number and mean root length taken at 7 DAP were not significantly different $(P<0.05)$ among the different treatments. Tables 6 and 7 show the mean root number and root length, respectively, of the maize as affected by the application of different rates of the compost.

Table 6. Mean plant height $(\mathrm{cm})$ of maize as influenced by different rates of compost treatment

\begin{tabular}{cccccccc}
\hline Compost & \multicolumn{7}{c}{ Days after planting } \\
\cline { 2 - 6 } Treatment & 7 & 14 & 21 & 28 & 35 & 42 & Mean \\
\hline $\mathrm{SC}_{0}$ & 7.8 & 13.1 & 18.8 & 25.0 & 21.3 & 32.8 & 21.5 \\
$\mathrm{SC}_{1}$ & 8.7 & 21.1 & 35.3 & 54.3 & 62.5 & 75.3 & 39.5 \\
$\mathrm{SC}_{2}$ & 9.4 & 23.4 & 36.5 & 56.8 & 67.5 & 82.0 & 45.9 \\
$\mathrm{SC}_{3}$ & 9.6 & 24.0 & 41.1 & 66.0 & 77.9 & 92.0 & 51.8 \\
$\mathrm{LSD}(\mathrm{P}=0.05)$ & $\mathrm{NS}$ & 3.84 & 6.90 & 5.50 & 7.90 & 10.19 & 6.10 \\
\hline
\end{tabular}

Key: $\mathrm{NS}=$ Not significant; $\mathrm{SC}_{0}=$ Soil only; $\mathrm{SC}_{1}=$ Soil +10 t ha ${ }^{-1}$ compost;

$\mathrm{SC}_{2}=$ Soil $+20 \mathrm{tha}^{-1}$ compost; $\mathrm{SC}_{3}=$ Soil $+40 \mathrm{tha}^{-1}$ compost. 
Table 7. Mean root length $(\mathrm{cm})$ of maize as influenced by various rates of compost treatment.

\begin{tabular}{cccccccc}
\hline \multirow{2}{*}{$\begin{array}{c}\text { Compost } \\
\text { treatment }\end{array}$} & 7 & 14 & 21 & 28 & 35 & 42 & Mean \\
\cline { 2 - 7 } & 7 & 8.75 & 8.75 & 9.25 & 9.50 & 10.75 & 9.20 \\
$\mathrm{SC}_{0}$ & 8.25 & 10.75 & 14.00 & 17.25 & 18.50 & 18.75 & 14.67 \\
$\mathrm{SC}_{1}$ & 8.75 & 10.75 & 15.75 & 19.25 & 19.25 & 21.25 & 15.88 \\
$\mathrm{SC}_{2}$ & 8.50 & 14.75 & 22.50 & 23.00 & 24.75 & 25.75 & 20.03 \\
$\mathrm{SC}_{3}$ & 9.95 & 1.51 & 2.56 & 1.43 & 1.23 & 1.61 & 1.39 \\
$\mathrm{LSD}(\mathrm{P}=0.05)$ & $\mathrm{NS}$ & &
\end{tabular}

Key: $\mathrm{NS}=$ Not significant; $\mathrm{SC}_{0}=$ Soil only; $\mathrm{SC}_{1}=$ Soil $+10 \mathrm{t}^{-1}$ compost;

$\mathrm{SC}_{2}=$ Soil $+20 \mathrm{t} \mathrm{ha}^{-1}$ compost; $\mathrm{SC}_{3}=+$ Soil $+40 \mathrm{t} \mathrm{ha}^{-1}$ compost.

Table 8 . Mean number of maize root as influenced by various rates of the compost treatment

\begin{tabular}{cccccccc}
\hline Compost & & \multicolumn{7}{c}{ Days after planting } \\
\cline { 3 - 7 } treatment & 7 & 14 & 21 & 28 & 35 & 42 & Mean \\
\hline $\mathrm{SC}_{0}$ & 9.00 & 11.25 & 11.50 & 12.25 & 12.75 & 13.00 & 11.63 \\
$\mathrm{SC}_{1}$ & 9.00 & 13.00 & 17.25 & 17.73 & 17.75 & 18.25 & 15.50 \\
$\mathrm{SC}_{2}$ & 9.25 & 15.00 & 19.75 & 20.50 & 20.75 & 20.75 & 17.75 \\
$\mathrm{SC}_{3}$ & 9.75 & 15.75 & 23.00 & 23.50 & 23.50 & 23.75 & 19.88 \\
$\mathrm{LSD}(\mathrm{P}=0.05)$ & $\mathrm{NS}$ & 3.37 & 1.58 & 1.98 & 1.75 & 1.69 & 1.73 \\
\hline
\end{tabular}

Key: $\mathrm{NS}=$ Not significant; $\mathrm{SC}_{0}=$ Soil only; $\mathrm{SC}_{1}=$ Soil $+10 \mathrm{t} \mathrm{ha}^{-1}$ compost;

$\mathrm{SC}_{2}=$ Soil $+20 \mathrm{t} \mathrm{ha}^{-1}$ compost $\mathrm{SC}_{3}=$ Soil $+40 \mathrm{tha}^{-1}$ compost.

Tables 5, 6 and 7 showed significant $(\mathrm{P}<0.05)$ increase in growth parameters (plant height, plant root number and plant root length) which were directly proportional to increase in DAP and also directly proportional to increase in levels of compost application. Significant growth and yield increases with the use of compost have been reported by Parr (1995) and Dowdy (1998).

\subsection{Dry Matter Weight (\%) of Maize Plant at 42 DAP}

The dry matter weight (\%) of maize plant taken from each treatment at 42 DAP indicated that there were significant different $(\mathrm{P}<0.05)$ in all the treatments. The highest percent dry matter weight was obtained from maize plant with no compost application (control or soil only) while the lowest dry matter was that of maize plant on fertilized with $40 \mathrm{tha}^{-1}$ compost application. The dry matter weight decreased with increase in rate of application of the compost.

Dry matter (\%) content expressed as the percent dry matter weight of the plant over the total fresh weight of same plant showed significant increase in maize planted on the control than treatments enriched with the compost. This might be enhanced by the increased water and nutrient absorption capacities of the compost fertilized plants resulting in high moisture content of the fertilized plants than those on the control. If the maize plants were to be fed to animals as forage, then maize plants grown on soil treated with compost (especially on soil with $40 \mathrm{t} \mathrm{ha}^{-1}$ of compost) will be preferred by animals. Akinola (1991) reported that dairy cows, fattening cattle and pregnant ewes need young leafy and highly digestible materials, which are very suitable at the early flowering stage. This is because the more favourable growth conditions of the maize plant fertilized with $40 \mathrm{t}$ $\mathrm{ha}^{-1}$ compost has higher non-protein $\mathrm{N}$ content as well as total $\mathrm{N}$ value which entails high digestibility since they are more crisp and succulent.

\section{Conclusion}

The beneficial effect of fertilizing maize with compost enhanced the significant growth and increased total dry matter yield of the crop which correlates with increase in the rate of compost applied. The increased soil nutrients in treated soils after harvesting of the crop can be attributed to the improvement in the nutrient and water holding capacities of the soil resulting from the application of the compost. 


\section{References}

Agboola, A. A. (1974). Problem of improving soil fertility by the use of green manuring in tropical farming system. In organic materials as fertilizers. Soil Bulletin (FAO), 27, 147-163.

Akinola, J. O. (1991). Forage conservation and utilization. In Training Manual for Range-Pasture Management Workshop (pp. 101-114). NAPRI, ABU, Shika Zaria.

Baathe, E. A., Frostergard, M., B-Ravina, D., \& Tunlid, A. (1998). Macrobial community based measurement to estimate heavy metal effect in soil. The use of phospholipids fatty acid patterns and bacterial community tolerance. AMBIO, 27, 58-61.

Bouyoucos, G. N. (1957). Recalibration of the hydrometer of soils. Agronomy Journal, 43, 434-438. http://dx.doi.org/10.2134/agronj1951.00021962004300090005x

Bray, R. H., \& Kurtz, L. T. (1945). Determination of total organic and available Phosphorus in soils. Soil Science, 59, 39-45. http://dx.doi.org/10.1097/00010694-194501000-00006

Carroll, S. (2011). Absorption of water and mineral in plants. Retrieved from www.eHow.com/Home

Dowdy, R. H., Clap, C. E., Linden, D. R., Larson, W. E., Halbach, T. R., \& Polta, R. C. (1994). Twenty years of trace metal partitioning on the Rosemont sewage water-shed. In C. E. Clap, W. E. Larson, \& R. H. Dowdy (Eds), Sewage sludge. Land Utilization and the Environment. Madison Wischotson. Soil Science Society of America, 13, 149-155.

Esenowo, G. A. (1994). Effect of some heavy metals on Germination and early seedling growth of two varieties of Hisbiens esculentis. West Africa Journal of Biological and Applied Chemistry, 40, 21-24.

Gomez, K. A., \& Gomez, A. A. (1984). Statistical procedure for agricultural research (p. 680). New York, USA: John Willey and Sons.

Hartley, K. T., \& Greenwood, T. (1933). The effect of small application of farmyard manure on the yield of cereals in Nigeria. Emp. Journal. Exp. Agriculture, 1, 119-121.

International Institute of Tropical Agriculture (IITA). (1979). Selected methods of soil and plant analysis. Manual No. 1, IITA, Ibadan.

Iren, O. B., Asawalam, D. O., Osodeke, V. E., \& John, N. M. (2011). Effects of animal manures and urea fertilizer as N sources for Amaranthus growth and yield in a rainforest Ultisol in Nigeria. World Journal of Applied Sciences and Technology, 3(1), 73-78.

Jackson, M. L. (1962). Soil chemical analysis (pp. 3-5). Prentice-Hall, Eaglewood Cliffs, N. J.

John, N. M. (2007). Heavy metals contents of Crude Oil sludge/municipal solid waste compost and Crude Oil sludge/poultry manure compost for Sustainable Crop Production. Agricultural Journal, 2(2), 281-284.

John, N. M., Etokeren, U. E., Udo, I. I., Edem, I. D., Iren, O. B., \& Asuquo, S. S. (2010). Effects of nitrogen enrichment on the heavy metals content of cattle dung/poultry manure compost and maize yield. Global Journal of Agricultural Sciences, 9(1), 51-55.

John, N. M., Ibia, T. O., Effiong, G. S., Etokeren, U. E., \& Iren, O. B. (2011). Response of maize (Zea mays L.) to different levels of decomposed refuse in Uyo municipality, Nigeria. World Journal of Applied and Technology, 3(1), 7-12. http://dx.doi.org/10.4314/gjass.v9i1.62791

Lal, R., \& Kang, B. T. (1982). Management of organic matter in soil of the tropics in non-symbiotic nitrogen fixation and organic matter in the tropic. Symposia papers 1-12. International congress of soil science, $150-178$.

Lombin, G., \& Abdullahi, A. (1978). Comparative effectiveness of separate and combined application of mineral fertilizers and farmyard manure in maintaining soil productivity under continuous cultivation. Samaru miscellaneous paper, $55,2$.

Lorton, S. R. (1996). A guide to natural soil enricher. An article in Sunset Magazine, Feb. 3, 12. U.S.A.

Murphy, J., \& Riley, J. P. (1962). A modified single solution method for the determination of phosphorus in natural waters. Annual chim Acta, 27, 31-36. http://dx.doi.org/10.1016/S0003-2670(00)88444-5

Nelson, D. W., \& Sommers, L. E. (1982). Total carbon, organic carbon and organic matter. In A. L. Miller, \& D. R. Energy (Eds.), Methods of soil analysis, Part 2. Amer. Soil of Agronomy Machison. (pp. 553-579).

Parr, J. F. (1975). Use of compost in Korea inorganic materials fertilizers. Report of the FAO/SIDA, 2. 
Sobulo, R. A. (2000). Fertilizer use and soil testing in Agronomy in Nigeria. Book presented on the theory and practice of Agronomy University of Ibadan Nigeria, 195-201.

Udo, E. J., Ibia, T. O., Ogunwale, J. A., Ano, A. O., \& Esu, I. E. (2009). Manual of soil, plant and water analysis (p. 103).

Uko, A. E., Udo, I. A., \& Shiyam, J. O. (2009). Optimizing poultry manure rates for two okro (Abelmoschus esculentus) varieties in a warm wet climate. Journal of Agriculture, Biotech. and Ecology, 2(3), 273-275.

Uwah, D. F., Eneji, A. E., \& Eshiet, U. J. (2011). Organic and mineral fertilizers effects on the performance of sweet maize (Zea mays 1. Saccharata strut.) In south eastern rainforest zone of Nigeria. Int'l J. Agric. Scis. 3(1), 54-61.

Uwah, D. F., Udoh, A. U., Okpara, D. A., Eka, M. J., \& Asawalam, D. O. (2011). Growth and yield of cocoyam (Colocasia esculenta (L.) Schott) following soil amendment with poultry manure and rice husk. J. Agric, Biotech \& Ecol., 4(2), 1-10. 